\title{
E-Government during the Pandemic: Maturity Assessment of the Provincial and Regency/City Website in West Sumatra
}

\author{
Amsal Djunid ${ }^{1}$, Asniati ${ }^{2}$, Rayna Kartika ${ }^{3}$ Indah Permata Suryani ${ }^{4}$, Ares Albirru Amsal ${ }^{5 *}$ \\ Faculty of Economics Universitas Andalas $1,2,3,4,5$ \\ *Email: aresalbirruasmal@eb.unand.ac.id
}

(Received: August 10-2020; revised: October 28-2020; published: December 31-2020)

\begin{abstract}
E-government uses information technology to change government relations with citizens, the private sector, and other institutions. The importance of identifying e-government performance cannot be separated from the use of the website. Thus, assessing the website quality is very important as it helps determine the quality of e-government services and improve service processes. In almost two years of implementing egovernment in West Sumatra, there has been no evaluation of the provincial and district/city government websites, which are the primary tools for implementing e-government today. In the Covid-19 pandemic period, the website's role has become more critical as a means for the public to get the latest information regarding developments in handling the pandemic. This study focuses on assessing and evaluating the level of maturity (maturity assessment) of the provincial and district/city government websites in implementing e-government and its relationship in response to the Covid-19 pandemic. Forty websites were assessed for their e-government maturity in this study. The website consists of 19 district/city websites, one provincial webpage, and 20 websites for handling Covid-19 for each district/city and province. The maturity assessment was measured using the United Nations (UN) e-government maturity model. This study found that government websites are still at stage 1 and stage 2 maturity models. Meanwhile, the Covid-19 handling website is on stage1. It is hoped that the government in West Sumatra will pay more attention to improving e-government through websites in the current pandemic era.
\end{abstract}

Keywords: E-government, UN maturity model, website

\section{INTRODUCTION}

E-government uses information technology that can transform relationships with citizens, the private sector, and government agencies (Worl Bank, 2012). This concept has a vital role in improving services (Grönlund, 2010) and has excellent efficiency potential, reducing corruption, encouraging revenue growth, increasing transparency, convenience, and facilitating public sector costs efficiency in developed and developing countries (Baguma and Lubega, 2013). ). Since the emergence of Information and Communication Technology (ICT), e-government has evolved and revolutionized the way services are provided to citizens. ICT has changed the interaction between government and citizens (Kumar and Vragov, 2009; Baguma and Lubega, 2013). The public sector has also recognized the use of ICTs to improve the quality and response of government services (Ndou, 2004). Thus, the emergence of e-government has made significant changes in delivering public services.

The importance of identifying e-government performance cannot be separated from the use of the website. Thus, conducting an assessment of the website's quality is very important as it helps identify issues that are important for e-government service quality and service process improvement. One of the significant models for assessing the maturity of e-government is the 
United Nations (UN) (United Nations, 2012), which has also been commonly used in various countries (United Nations, 2016).

In developing countries, e-government is still in early development and has not been entirely successful. In fact, according to Dada (2006), the majority of e-government in developing countries has failed. It can be due to the country's complexity, lack of resources, socio-culture, and other challenges that need to be addressed (Wireko and Skouby, 2016).

Presidential Instruction No. 3 of 2003 regarding national policies and strategies for egovernment development is a step to encourage governance by utilizing information and communication technology (IT) infrastructure. Through a circular to several government agencies, governors, and regents/mayors, the government mandates institutional leaders and regional heads to nationally encourage the implementation of e-government.

West Sumatra Province has enacted the Draft Perda SPBE (Electronic Based Government System) / e-Government management to become Perda number 31 of 2018 on 27 November 2018. The enactment of this legislation is expected to support good governance in community services supported by information technology systems and communication (Dasril, 2016). In almost two years of implementing e-government in West Sumatra, there has been no evaluation of the provincial and district/city government websites, which are the primary tools for implementing egovernment today.

With the Covid-19 pandemic period, the website's role has become more critical as a means for the public to get the latest information regarding developments in handling the pandemic. Therefore, the need to identify the maturity status of the current website becomes even more crucial.

\section{E-Government}

E-government is applying information technology to deliver information and services to citizens, businesses, and other parties with government interest (Dasril, 2016). E-government can be used to the legislative, judicial, or public administration aspects to increase government efficiency, provide public services, or the democratic state process. There are three main models of e-government, namely, Government-to-Citizen or Government-to-Customer (G2C), Government-to-Business (G2B), and Government-to-Government (G2G). The main benefits of e-government are increased efficiency, convenience, and better accessibility of public services.

E-government includes using ICT, including the internet, databases, networks, online discussions, multimedia, automation, tracking and tracing, and personal data identification technology (Jaeger, 2003). The many benefits obtained from implementing e-government have led many state governments to invest heavily in this technology and system (Angelopoulos, Kitsios, and Papadopoulos, 2009). This technology offers authorities services to connect electronically with the government (Alshehri, Mohammed; Drew, 2010). With different types of services tailored to users' needs, an increase in the development of different types of e-government is inevitable.

Maturity levels should be identified and analyzed based on the level of information technology that has been used to perform service delivery electronically (Seifert, 2003). It can be achieved through the use of an appropriate e-government maturity model. The maturity model is a method for assessing an organization's process maturity and identifying the primary practices 
400 Jurnal Ilmiah Ilmu Administrasi Publik: Jurnal Pemikiran dan Penelitian Administrasi

Volume 10 Number 2, July-December 2020. Page 398-408

needed to increase an organization's processes (Windley, 2002). This model serves as a guide to gain control over developing and maintaining e-government services, especially those that are directly accessed by the public via the website.

\section{United Nation Four-Stage Model}

There are several models of e-government maturity, such as those developed by Layne and Lee (2001), Hiller and Billanger (2001), the United Nations (2012), and the World Bank (2002). According to a comparative study conducted by Almuftah, Weerakkody, \& Sivarajah (2016), the UN model displays an emphasis on citizens, electronic participation, focusing on citizens' needs who push for transparent and effective e-government. Thus, in this study, the United Nations (UN) four-stage e-government maturity model was chosen. Each stage of e-government development has its level of technological features and sophistication.

The first stage is a service that appears on a government website with necessary government information, public policy, governance or regulation, and links to other government branches. Here, citizens can get the latest information about the government.

The second stage is service improvement, whereby government websites contain simple one-way or two-way communication media for citizens, such as downloading forms and applications. This feature can have multi-language and audio/video capabilities.

The third stage is transactional services, where a government website provides two-way communication capabilities for citizens, such as applying for certificates, permits, and licenses; and download and upload forms. At this stage, the website can also serve financial transactions for the payment of taxes or fines.

The fourth stage is an integrated service where the government can be proactive in engaging citizens, thus providing interactive web tools on the website. Information, data, and knowledge are transferred from government agencies through integrated applications. At this stage, citizens are empowered and given tools to be more involved in government activities and decisionmaking.

\section{METHOD}

The research subjects are the websites of the provincial and district/city governments in West Sumatra. A total of 40 government website sites in West Sumatra were recorded for evaluation. The website must be an official government address marked with the ".go.id" domain. This research's object is e-government maturity, which is measured based on the e-government maturity model of the United Nations (United Nations, 2012). A list of websites for which the maturity level will be measured can be seen in the table below.

\begin{tabular}{l|l|l} 
Government & Website & Website Covid-19 \\
\hline $\begin{array}{l}\text { Province } \\
\text { Sumatera Barat }\end{array}$ & sumbarprov.go.id & corona.sumbarprov.go.id \\
\hline District & agamkab.go.id & covid19.agamkab.go.id \\
\hline Agam & dharmasrayakab.go.id & covid-19.dharmasrayakab.go.id \\
\hline Dharmasraya
\end{tabular}




\begin{tabular}{l|l|l} 
Government & Website & Website Covid-19 \\
\hline $\begin{array}{l}\text { Kepulauan } \\
\text { Mentawai }\end{array}$ & mentawaikab.go.id & covid19.mentawaikab.go.id \\
\hline Lima Puluh Kota & limapuluhkotakab.go.id & covid19.limapuluhkotakab.go.id \\
\hline Padang Pariaman & padangpariamankab.go.id & covid19.padangpariamankab.go.id \\
\hline Pasaman & pasamankab.go.id & corona.pasamankab.go.id \\
\hline Pasaman Barat & pasamanbaratkab.go.id & corona.pasamanbaratkab.go.id \\
\hline Pesisir Selatan & pesisirselatankab.go.id & covid19.pesisirselatankab.go.id \\
\hline Sijunjung & sijunjung.go.id & covid-19.sijunjung.go.id \\
\hline Solok & solokkab.go.id & covid19.solokkab.go.id \\
\hline Solok Selatan & solselkab.go.id & corona.solselkab.go.id \\
\hline Tanah Datar & tanahdatar.go.id & covid-19.tanahdatar.go.id \\
\hline City & & \\
\hline Bukittinggi & bukittinggikota.go.id & covid19.bukittinggikota.go.id \\
\hline Padang & padang.go.id & corona.padang.go.id \\
\hline Padangpanjang & padangpanjang.go.id & corona.padangpanjang.go.id \\
\hline Pariaman & pariamankota.go.id & corona.pariamankota.go.id \\
\hline Payakumbuh & payakumbuhkota.go.id & covid19.payakumbuhkota.go.id \\
\hline Sawahlunto & sawahluntokota.go.id & covid19.sawahluntokota.go.id \\
\hline Solok & solokkota.go.id & corona.solokkota.go.id
\end{tabular}

The website was determined by listing all provincial and district/city websites in West Sumatra and the Covid-19 pandemic response website. From a government perspective, the website is divided into 3, namely the provincial, district, and city levels. Meanwhile, based on the type, the website is divided into 2, namely the main website and the Covid-19 response website.

To identify the URL, Google is used to search, and the website containing the ".go.id" domain is used for the assessment. The Covid-19 response website is a subdomain of the main website. These websites will be observed and analyzed based on the United Nations (UN) egovernment maturity model.

The measurement will be based on the United Nations (UN) e-government maturity model. A website is in a particular stage if the web features meet all the criteria given, except Stage 1 where a mere online presence (URL provided) is considered stage 1. The results of the observations are then transferred to a spreadsheet. The data were then analyzed using descriptive statistical methods.

A website is rated a Stage 1 website if it meets at least one of the features for that stage. In this paper, an online presence with necessary government information published is already considered stage 1 . For hold 2 and beyond, if a website meets all the criteria at a particular stage, it is then rated as the next advanced stage. For example, if a website meets all of the Stage 2 criteria, it is considered a Stage 3 website.

The observation data will then be analyzed using descriptive statistical methods. The results of the analysis will answer the formulation of research problems, namely; the maturity level of 
402 Jurnal Ilmiah Ilmu Administrasi Publik: Jurnal Pemikiran dan Penelitian Administrasi

Volume 10 Number 2, July-December 2020. Page 398-408

the e-government website of the provincial and district/city governments in West Sumatra, the maturity level of the e-government websites of the provincial and district/city governments in West Sumatra in handling Covid-19, aspects of the website that can be improved to improve egovernment management in West Sumatra, especially during the pandemic.

\section{RESULT AND DISCUSSION}

All 40 websites studied could be adequately accessed to assess their maturity criteria. Each website is evaluated based on Khalid and Lavilles (2019) criteria using the United Nations model. Each stage has 4-5 measures and is assessed separately. A website is categorized as stage 1 if it has at least one existing criteria. If a website has all the requirements at a particular stage, it is classified as the next stage.

The first assessment was carried out on the main government website with the results in the table below.

\begin{tabular}{lcccc}
\hline Government & \multicolumn{2}{c}{ Stage 1 } & \multicolumn{2}{c}{ Stage 2 } \\
\hline Kabupaten & Q & $\%$ & Q & $\%$ \\
Kota & 7 & $58 \%$ & 5 & $42 \%$ \\
Provinsi & 3 & $43 \%$ & 4 & $57 \%$ \\
Total & 10 & $50 \%$ & 10 & $50 \%$ \\
\hline
\end{tabular}

In table 6, we can see that the number of websites on stage 1 and stage 2 is the same, namely 10 . Each district website is on stage 1 with a ratio of $7: 5$. Meanwhile, more city websites are on stage 2 with a thin ratio of 3: 4 . The provincial website is classified as stage 2 .

Government websites at stage 1 and stage 2 can be seen in the table below.

\begin{tabular}{lll}
\hline \multicolumn{1}{c}{ Stage 1 } & \multicolumn{1}{c}{ Stage 2 } \\
\hline 1. Kab. Kepulauan Mentawai & 11. Kab. Lima Puluh Kota \\
2. Kota Padang & 12. Kab. Solok \\
3. Kota Pariaman & 13. Kota Bukittinggi \\
4. Kab. Agam & 14. Kab. Pasaman \\
5. Kota Sawahlunto & 15. Kab. Pasaman Barat \\
6. Prov. Sumatera Barat & 16. Kab. Pesisir Selatan \\
7. Kab. Padang Pariaman & 17. Kota Padangpanjang \\
8. Kab. Solok Selatan & 18. Kab. Dharmasraya \\
9. Kab. Tanah Datar & 19. Kab. Sijunjung \\
10. Kota Payakumbuh & 20. Kota Solok \\
\hline
\end{tabular}


The results of a search for government websites at stage 1 show that "information about the office" is a criterion that all websites have. Meanwhile, the criterion "contact us feature" is the lowest criterion.

\begin{tabular}{lccccc}
\hline \multicolumn{7}{c}{ Kriteria Stage 1 } \\
\hline Government & $\begin{array}{c}\text { information about } \\
\text { the office }\end{array}$ & $\begin{array}{c}\text { Search } \\
\text { Engine }\end{array}$ & $\begin{array}{c}\text { Links to other offices / } \\
\text { organizations }\end{array}$ & Renewing & $\begin{array}{c}\text { contact us } \\
\text { feature }\end{array}$ \\
\hline Kabupaten & 12 & 10 & 11 & 11 & 9 \\
Kota & 7 & 6 & 7 & 7 & 5 \\
Provinasi & 1 & 1 & 1 & 1 & 1 \\
\hline Total & 20 & 17 & 19 & 19 & 15 \\
\hline
\end{tabular}

In stage 2, the criteria for 'audio / visual assistance' is owned by 11 websites and the 'feedback' criteria is owned by 7 websites. None of the yam websites have other criteria in stage 2 .

\begin{tabular}{lccccc}
\hline \multicolumn{5}{c}{ Kriteria Stage 2 } \\
Government & $\begin{array}{c}\text { Downloadable } \\
\text { form }\end{array}$ & $\begin{array}{c}\text { The criteria for 'audio / } \\
\text { visual assistance }\end{array}$ & Multilingual & feedback Registration \\
\hline Kabupaten & 0 & 6 & 0 & 4 & 0 \\
Kota & 0 & 4 & 0 & 3 & 0 \\
Provinasi & 1 & 11 & 0 & 7 & 0 \\
\hline Total & 0 & & & \\
\hline
\end{tabular}

In stage 3 , no website has these criteria.

\begin{tabular}{lcccc}
\hline \multicolumn{5}{c}{ Kriteria Stage 3 } \\
\hline Government & $\begin{array}{c}\text { Upload } \\
\text { Form }\end{array}$ & $\begin{array}{c}\text { Financial } \\
\text { Transactions }\end{array}$ & $\begin{array}{c}\text { Sign up for a certificate } \\
\text { or license }\end{array}$ & E-voting \\
\hline Kabupaten & 0 & 0 & 0 & 0 \\
Kota & 0 & 0 & 0 & 0 \\
Provinasi & 0 & 0 & 0 & 0 \\
\hline Total & 0 & 0 & 0 & 0 \\
\hline
\end{tabular}

At stage 4, two websites have the criteria for 'web comment forms' and one website has the criteria for 'online consultation'.

\begin{tabular}{lccc}
\hline Government & $\begin{array}{c}\text { Keb comment } \\
\text { form }\end{array}$ & online & $\begin{array}{c}\text { consultation Participation in } \\
\text { decision making }\end{array}$ \\
\hline Kabupaten & 1 & 1 & 0 \\
Kota & 1 & 0 & 0 \\
Provinasi & 0 & 0 & 0 \\
\hline Total & 2 & 1 & 0 \\
\hline
\end{tabular}


404 Jurnal Ilmiah Ilmu Administrasi Publik: Jurnal Pemikiran dan Penelitian Administrasi Publik

Volume 10 Number 2, July-December 2020. Page 398-408

The website of Mentawai Regency has the highest score (8) followed by the districts of Fifty Cities, Kota Padang, and Kota Pariaman (7). The mean score was 5.5 overall.

\begin{tabular}{llc}
\hline GOVERNMENT & & Score \\
\hline Kab. Kepulauan Mentawai mentawaikab.go.id & 8 \\
Kab. Lima Puluh Kota & limapuluhkotakab.go.id & 7 \\
Kota Padang & padang.go.id & 7 \\
Kota Pariaman & pariamankota.go.id & 7 \\
Kab. Agam & agamkab.go.id & 6 \\
Kab. Solok & solokkab.go.id & 6 \\
Kota Bukittinggi & bukittinggikota.go.id & 6 \\
Kota Sawahlunto & sawahluntokota.go.id & 6 \\
Prov. Sumatera Barat & sumbarprov.go.id & 6 \\
Kab. Padang Pariaman & padangpariamankab.go.id & 5 \\
Kab. Pasaman & pasamankab.go.id & 5 \\
Kab. Pasaman Barat & pasamanbaratkab.go.id & 5 \\
Kab. Pesisir Selatan & pesisirselatankab.go.id & 5 \\
Kab. Solok Selatan & solselkab.go.id & 5 \\
Kab. Tanah Datar & tanahdatar.go.id & 5 \\
Kota Padangpanjang & padangpanjang.go.id & 5 \\
Kota Payakumbuh & payakumbuhkota.go.id & 5 \\
Kab. Dharmasraya & dharmasrayakab.go.id & 4 \\
Kab. Sijunjung & sijunjung.go.id & 4 \\
Kota Solok & solokkota.go.id & 4 \\
\hline Average & & 5.55 \\
\hline
\end{tabular}

Next, researchers examined the link to the covid-19 website. Only 5 out of 20 websites have links to the Covid-19 website, namely Agam district, Mentawai Kepulaian district, South Solok district, Padang City, and Solok City.

\begin{tabular}{llc}
\hline GOVERNMENT & & Link \\
\hline Agam & agamkab.go.id & Yes \\
Dharmasraya & dharmasrayakab.go.id & 0 \\
Kepulauan Mentawai mentawaikab.go.id & Yes \\
Lima Puluh Kota & limapuluhkotakab.go.id & 0 \\
Padang Pariaman & padangpariamankab.go.id & 0 \\
Pasaman & pasamankab.go.id & 0 \\
Pasaman Barat & pasamanbaratkab.go.id & 0 \\
Pesisir Selatan & pesisirselatankab.go.id & 0 \\
Sijunjung & sijunjung.go.id & 0
\end{tabular}


Amsal Djunid, Asniati, Rayna Kartika, Indah Permata Suryani, Ares Albirru Amsal; E-Gov... | 405

\begin{tabular}{llc} 
Solok & solokkab.go.id & 0 \\
Solok Selatan & solselkab.go.id & yes \\
Tanah Datar & tanahdatar.go.id & 0 \\
Total & & 3 \\
\hline KOTA & & Link \\
\hline Bukittinggi & bukittinggikota.go.id & 0 \\
Padang & padang.go.id & Yes \\
Padangpanjang & padangpanjang.go.id & 0 \\
Pariaman & pariamankota.go.id & 0 \\
Payakumbuh & payakumbuhkota.go.id & 0 \\
Sawahlunto & sawahluntokota.go.id & 0 \\
Solok & solokkota.go.id & Yes \\
Total & & 2 \\
\hline PROVINSI & & Yes \\
\hline Sumatera Barat & sumbarprov.go.id & 0 \\
\hline
\end{tabular}

All websites handling covid-19 are on stage 1. The highest score is owned by the Pasaman Regency website (6), and the lowest score is the Padang city website (2).

\begin{tabular}{llccccc}
\hline GOVERNMENT & Website & Stage 1 Stage 2 & Stage 3 Stage 4 Total \\
\hline Kab. Pasaman & corona.pasamankab.go.id & 4 & 2 & 0 & 0 & 6 \\
Kab. Dharmasraya & covid-19.dharmasrayakab.go.id & 4 & 1 & 0 & 0 & 5 \\
Kab. Solok & covid19.solokkab.go.id & 4 & 1 & 0 & 0 & 5 \\
Kab. Solok Selatan & corona.solselkab.go.id & 4 & 1 & 0 & 0 & 5 \\
Kota Padangpanjang & corona.padangpanjang.go.id & 4 & 1 & 0 & 0 & 5 \\
Kab. Kep. Mentawai & covid19.mentawaikab.go.id & 4 & 0 & 0 & 0 & 4 \\
Kab. 50Kota & covid19.limapuluhkotakab.go.id & 3 & 1 & 0 & 0 & 4 \\
Kab. Padang Pariaman & covid19.padangpariamankab.go.id & 3 & 1 & 0 & 0 & 4 \\
Kab. Pasaman Barat & corona.pasamanbaratkab.go.id & 4 & 0 & 0 & 0 & 4 \\
Kab. Pesisir Selatan & covid19.pesisirselatankab.go.id & 3 & 1 & 0 & 0 & 4 \\
Kab. Sijunjung & covid-19.sijunjung.go.id & 3 & 1 & 0 & 0 & 4 \\
Kota Pariaman & corona.pariamankota.go.id & 3 & 1 & 0 & 0 & 4 \\
Kota Sawahlunto & covid19.sawahluntokota.go.id & 4 & 0 & 0 & 0 & 4 \\
Prov. Sumbar Barat & corona.sumbarprov.go.id & 4 & 0 & 0 & 0 & 4 \\
Kab. Agam & covid19.agamkab.go.id & 3 & 0 & 0 & 0 & 3 \\
Kab. Tanah Datar & covid-19.tanahdatar.go.id & 3 & 0 & 0 & 0 & 3 \\
Kota Bukittinggi & covid19.bukittinggikota.go.id & 3 & 0 & 0 & 0 & 3 \\
Kota Payakumbuh & covid19.payakumbuhkota.go.id & 3 & 0 & 0 & 0 & 3 \\
Kota Solok & corona.solokkota.go.id & 3 & 0 & 0 & 0 & 3 \\
Kota Padang & corona.padang.go.id & 2 & 0 & 0 & 0 & 2 \\
\hline
\end{tabular}

On average a website has 3 out of 5 criteria on stage 1 . However, no website has the criteria for 'search facilities'. 


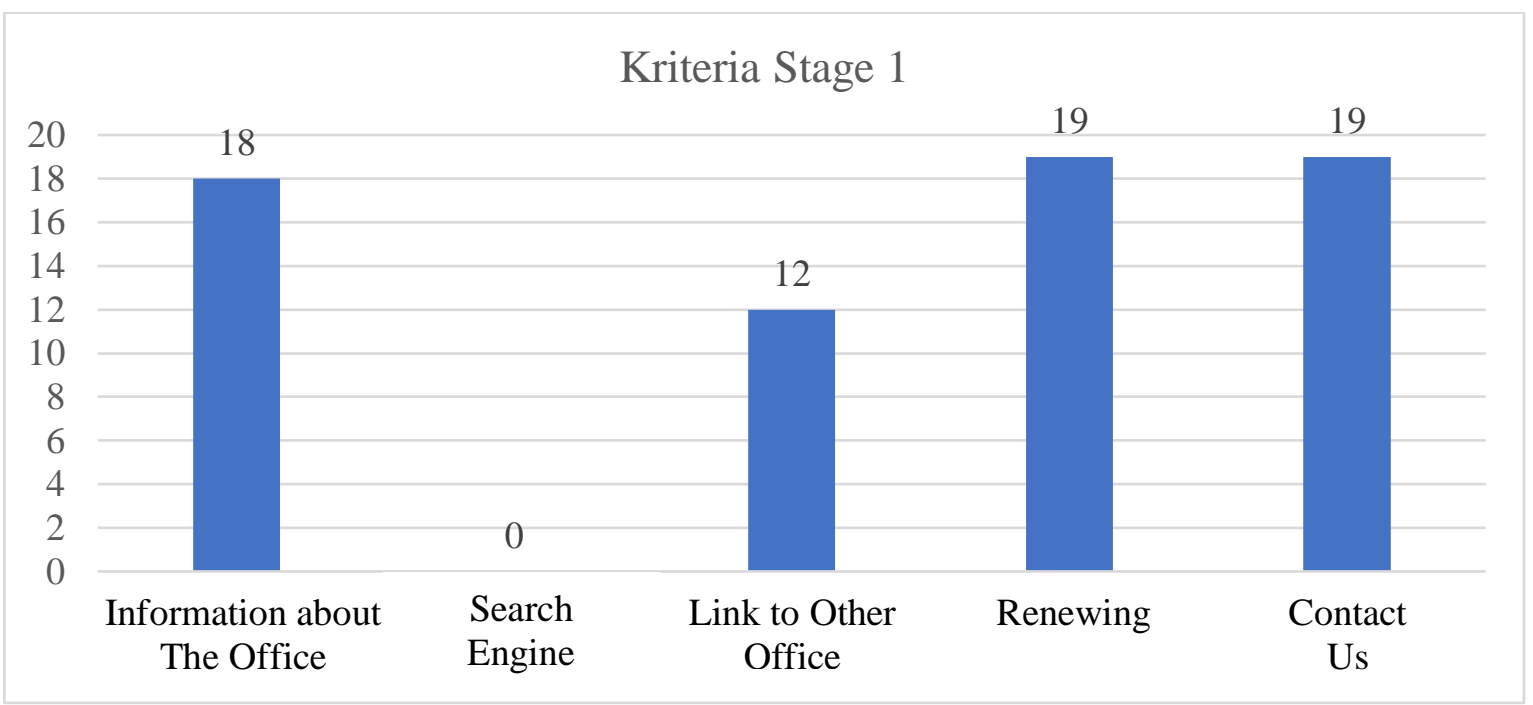

At stage 2, only 2 out of 5 criteria are owned by the website, namely "audio / visual capability" (3) and the "feedback" criterion (5).

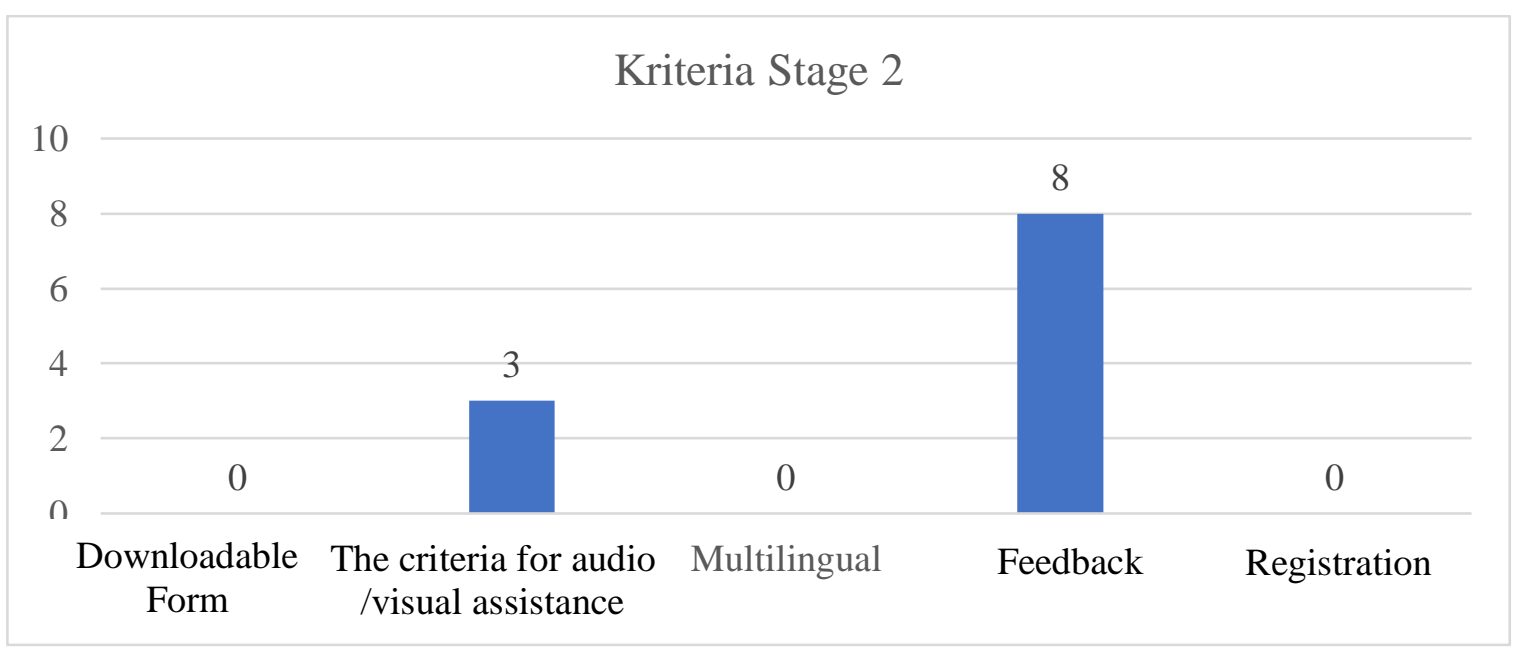

\section{CONCLUSION}

This study evaluates the current status of local government websites in West Sumatra. The research findings reveal several implications. First, the majority of the main government websites in West Sumatra are in an early maturity phase. The website is on stage 1 and stage 2 as a whole. This means that it needs to strengthen government initiatives towards e-government related to websites. Second, only five out of twenty websites assessed have links to websites dealing with Covid-19. Providing a link on the website is expected to make it easier for people to find official information about Covid-19 in their respective regions. Third, the covid-19 website is entirely at stage 1 . This is not too surprising because the new website was built after the pandemic phase 
occurred. However, there is no single website with a 'search' feature, limiting covid-19 information search activities.

\section{REFERENCES}

Almuftah, H., Weerakkody, V. and Sivarajah, U. (2016) 'Comparing and Contrasting eGovernment Maturity Models : A Qualitative-Meta Synthesis', Electronic Government and Electronic Participation, 0, pp. 69-79. doi: 10.3233/978-1-61499-670-5-69.

Alshehri, Mohammed;Drew, S. (2010) 'E-Government Fundamentals Author EGOVERNMENT FUNDAMENTALS', Proceedings of the IADIS International Conference ICT, Society and Human beings, pp. 35-42.

Angelopoulos, S., Kitsios, F. and Papadopoulos, T. (2009) New service development in eGovernment: Identifying Critical Success Factors, Transforming Government People Process and Policy.

Baguma, R. and Lubega, J. (2013) 'Factors for success and failure of e-government projects: The case of e-government projects in Uganda', in ACM International Conference Proceeding Series. New York, New York, USA: Association for Computing Machinery, pp. 194-197. doi: $10.1145 / 2591888.2591921$.

Bank, W. (2002) Issue Note: E-Government and the World Bank.

Bank and World (2012) 'ICT for greater development impact: World Bank Group Strategy for 2012-2015', pp. 1-79.

Dada, D. (2006) 'The Failure of E-Government in Developing Countries: A Literature Review', EJISDC, 26. doi: 10.1002/j.1681-4835.2006.tb00176.x.

Dasril, R. K. (2016) Tentang e-Government, Biro Umum.

Grönlund, Å. (2010) 'Ten years of E-government: The "End of History” and new beginning', in Lecture Notes in Computer Science (including subseries Lecture Notes in Artificial Intelligence and Lecture Notes in Bioinformatics). Springer, Berlin, Heidelberg, pp. 13-24. doi: 10.1007/978-3-642-14799-9_2.

Hiller, J. and Belanger, F. (2001) 'Privacy Strategies for Electronic Government', E-government Series, pp. 162-198.

Jaeger, P. T. (2003) 'The Endless Wire: E-Government as a Global Phenomenon', Government Information Quarterly, 20(4), pp. 323-31.

Khalid, S. A. and Lavilles, R. Q. (2019) 'Maturity Assessment of Local E-government Websites in the Philippines', Procedia Computer Science. Elsevier B.V., 161, pp. 99-106. doi: 10.1016/j.procs.2019.11.104. 
408 | Jurnal Ilmiah Ilmu Administrasi Publik: Jurnal Pemikiran dan Penelitian Administrasi Publik

Volume 10 Number 2, July-December 2020. Page 398-408

Kumar, N. and Vragov, R. (2009) 'Active citizen participation using ICT tools', Communications of the ACM, 52(1), pp. 118-121. doi: 10.1145/1435417.1435444.

Layne, K. and Lee, J. (2001) 'Developing Fully Functional E-Government: A Four Stage Model', Government Information Quarterly, 18, pp. 122-136. doi: 10.1016/S0740624X(01)00066-1.

Nations, U. (2012) “E-Government for The People." UN E-Government Survey.

Nations, U. (2016) "E-Government in Support of Sustainable Development.” UNE-

Government Survey.

Ndou, V. D. (2004) 'E-Government for Developing Countries: Opportunities and Challenges', The Electronic Journal of Information Systems in Developing Countries. Wiley-Blackwell, 18(1), pp. 1-24. doi: 10.1002/j.1681-4835.2004.tb00117.x.

Seifert, J. W. (2003) 'A Primer on E-Government: Sectors, Stages, Opportunities, and Challenges of Online Governance', Report for Congress, p. 24. doi: RL31057.

Windley, P. J. (2002) 'eGovernment maturity', Phil Windleys’ Technometria.

Wireko, J. K. and Skouby, K. E. (2016) 'Transition to e-government in Developing countries: The Case of Driver and Vehicle Licensing Authority (DVLA) e-Service Smart City Initiatives in Ghana', in. International Telecommunications Society, pp. 8-10. 